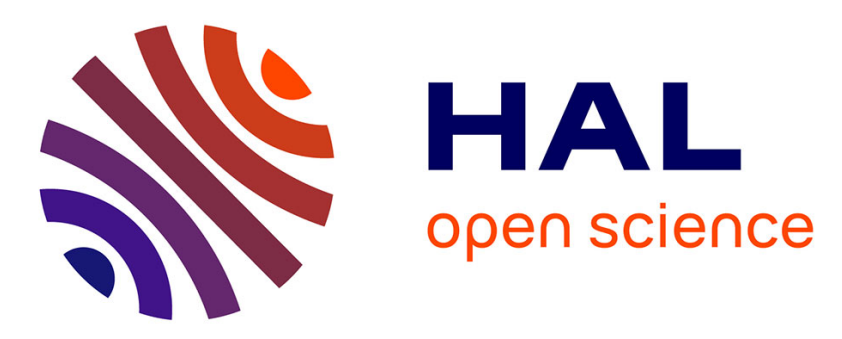

\title{
Bioturbation in the Venice Lagoon: Rates and relationship to organisms
}

\author{
Magali Gérino, Mauro Frignani, Cristian Mugnai, Luca Giorgio Bellucci, \\ Daniela Prevedelli, Andrea Valentini, Alberto Castelli, Sebastien Delmotte, \\ Sabine Sauvage
}

\section{To cite this version:}

Magali Gérino, Mauro Frignani, Cristian Mugnai, Luca Giorgio Bellucci, Daniela Prevedelli, et al.. Bioturbation in the Venice Lagoon: Rates and relationship to organisms. Acta Oecologica, 2007, 32, pp.14-25. 10.1016/j.actao.2007.02.003 . hal-00793425

\section{HAL Id: hal-00793425 https://hal.science/hal-00793425}

Submitted on 22 Feb 2013

HAL is a multi-disciplinary open access archive for the deposit and dissemination of scientific research documents, whether they are published or not. The documents may come from teaching and research institutions in France or abroad, or from public or private research centers.
L'archive ouverte pluridisciplinaire HAL, est destinée au dépôt et à la diffusion de documents scientifiques de niveau recherche, publiés ou non, émanant des établissements d'enseignement et de recherche français ou étrangers, des laboratoires publics ou privés. 


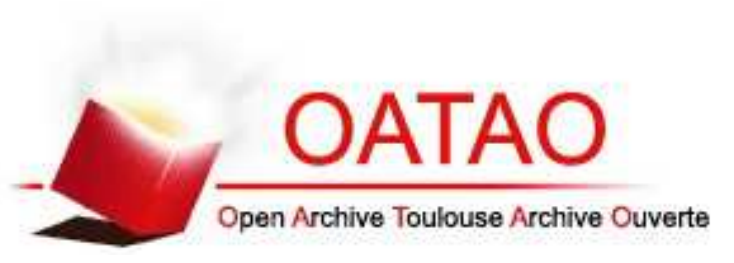

\section{Open Archive Toulouse Archive Ouverte (OATAO)}

OATAO is an open access repository that collects the work of Toulouse researchers and makes it freely available over the web where possible.

This is an author-deposited version published in: http://oatao.univ-toulouse.fr/ Eprints ID: 5875

To link to this article: DOI:10.1016/j.actao.2007.02.003

URL: http://dx.doi.org/10.1016/j.actao.2007.02.003

To cite this version: Gérino, Magali and Frignani, Mauro and Mugnai, Cristian and Bellucci, Luca Giorgio and Prevedelli, Daniela and Valentini, Andrea and Castelli, Alberto and Delmotte, Sébastien and Sauvage, Sabine Bioturbation in the Venice Lagoon: Rates and relationship to organisms. (2007) Acta Oecologica, vol. 32 (n¹). pp. 14-25. ISSN 1146$609 \mathrm{X}$

Any correspondence concerning this service should be sent to the repository administrator: staff-oatao@ listes.diff.inp-toulouse.fr 


\title{
Bioturbation in the Venice Lagoon: Rates and relationship to organisms
}

\author{
Magali Gerino ${ }^{a, *}$, Mauro Frignani ${ }^{b}$, Cristian Mugnai ${ }^{b}$, Luca G. Bellucci $^{b}$, Daniela Prevedellic, \\ Andrea Valentinic, Alberto Castelli ${ }^{d}$, Sebastien Delmotte ${ }^{a}$, Sabine Sauvage ${ }^{a}$ \\ aUMR CNRS/UPS/INP 5245 EcoLab, Laboratoire d'Ecologie Fonctionnelle, 29 Rue J. Marvig, 31055 Toulouse Cedex 4, France \\ ${ }^{b}$ CNR-Istituto di Scienze Marine, Sede di Bologna - Geologia Marina, Via Gobetti 101, 40129 Bologna, Italy \\ ${ }^{c}$ Dipartimento di Biologia Animale, Università di Modena e Reggio Emilia, Via Campi 213/d, 41100 Modena, Italy \\ dDipartimento di Scienze dell’Uomo e dell'Ambiente, Università di Pisa, Via delle Belle Torri 18, 56127 Pisa, Italy
}

Keywords:

Bioturbation

Sediment mixing rates

Modeling

Functional groups

Venice Lagoon

\begin{abstract}
A B S T R A C T
Experiments were carried out during autumn 1998 and spring 1999 at four selected sites in the Venice Lagoon in order to estimate the major bioturbation modes, and for quantitative analysis of the contribution of various taxa to these modes. Fluorescent sediment particles (63-350 $\mu \mathrm{m})$ were supplied as a tracer pulse input at the sediment surface. Tracer depth profiles obtained after 15 and 20 days were simulated with a diffusion-advection-non-local transport model. This allowed the rates of biodiffusion $\left(D_{b}\right)$, bioadvection $(W)$, and $R S$, a non-local transport coefficient to account for the displacement of sediment by regeneration, to be estimated. A combination of fresh water and marine organisms were responsible for the recorded sediment reworking, which was dominated by both types of non-local transports (conveying and regeneration). Considering all the sampling sites and seasons, $D_{\mathrm{b}}$ ranged from $0.87 \pm 0.02$ to $3.17 \pm 0.92 \mathrm{~cm}^{2} \mathrm{y}^{-1}$, W from $0.12 \pm 0.09$ to $27.41 \pm 2.47 \mathrm{~cm} \mathrm{y}^{-1}$ and RS from $0.00 \pm 0.00$ to $5.47 \pm 1.09 \mathrm{~g} \mathrm{~cm}^{-2} \mathrm{y}^{-1}$ (mean $\pm \mathrm{SE}, n=3$ ). A multiple regression analysis was applied to identify the contribution from individual species to sediment transport types. Biodiffusion resulted from the combined activity of polychaetes such as Spio decoratus and meiobenthic harpacticoïd copepods, while the polychaete Hediste diversicolor was mainly responsible for regeneration. Conveying processes were driven by another polychaete, Capitella capitata. Despite heterogeneity in the benthic community composition, biodiffusion and regeneration rates did not vary significantly between sites or season, with only bioadvection found to be higher in spring than in autumn.
\end{abstract}

\section{Introduction}

Bioturbation is a process of sediment mixing that results from macrofauna burrowing, feeding and reworking at and below the sediment-water interface. This mixing has profound effects on both the physical and the geochemical proprieties of the surficial sediments (Rhoads, 1974; Aller, 1982). Furthermore, these activities affect the stratigraphic record by

\footnotetext{
* Corresponding author. Fax: +33 562269999.

E-mail address: gerino@cict.fr (M. Gerino).
} 
spatially redistributing sedimentary materials such as microfossils and sediment associated chemical species (Berger and Heath, 1968; Guinasso and Schink, 1975; Cochran, 1985) and influence both rates of organic matter decomposition and biogeochemical cycles (Berner, 1980).

Different modes of bioturbation have been described in the literature. Some crustacean, bivalves and echinoderma process surface sediment in the uppermost few centimetres in the majority of cases and may extend to depth of several decimetres for some celebrated burrower species like anomuran simply by crawling on or plowing through it (Bromley, 1990). The physiological activities of surficial macrobenthos, like feeding and moving, generate omni-directional particle transport that is modelled by analogy with diffusive processes. Sub-surface deposit feeding benthos, which feed at depth and transport material to the sediment surface, generate a non-local-transport defined as conveying (Boudreau, 1997). More precisely, the intensive deposition of faecal pellets at the sediment surface leads to burial and advection of surface sediment with a vertical velocity usually one order of magnitude larger than physical sedimentation rates (Robbins et al., 1979; Fisher et al., 1980; Rice, 1986; Gerino et al., 1994). Mainly polychaetes and oligochetes, called "conveyor-belt feeders" (Rhoads, 1974), are responsible for this process and their effect is quantified as bioadvection (Gerino et al., 1994; Mugnai et al., 2003). A third type of mixing process is a nonlocal transport called regeneration (Smith et al., 1986/87; Gardner et al., 1987; François et al., 1997) that is produced by large burrow-digging organisms. They are responsible for the net movement of superficial sediment to the bottom of the burrows after they have been deserted, which is quantified as a downward non-local flux. Previous measurements of these different bioturbation modes in the Venice lagoon (Mugnai et al., 2003) and other estuarine sediments (Gerino et al., $1994,1998)$ have shown that non-diffusive transport processes dominate biological sediment reworking.

Up until now, the bio-transport modes of a few "pilot like" organisms, like polychetes Hediste diversicolor and Capitella capitata and oligochetes Tubifex tubifex have been identified from laboratory experiments run with monospecific populations (Fisher et al., 1980; Gerino and Stora, 1991; Salen-Picard et al., 1994). Identification of other organisms that compose each functional group of bioturbators at a given site is important to predict bioturbation modes and intensities: the composition of bioturbation groups may be used in combination with information about temperature, sediment organic matter contents and sediment contamination (McCall and Tevest, 1982; Rice, 1986) that are known to control intensity of organisms-mediated processes.

This paper firstly aim was to extend measurements of bioturbation in the Venice Lagoon to various locations selected to represent a pollution gradient and determine the relative contribution of the different biogenic mixing processes (biodiffusive, bioadvective and non-local transport). Secondly, the effects of site, season and benthic species densities were examined to identify factors which cause major variation in the intensity of bioturbation within the lagoon. Finally, the third aim of this paper was to identify and quantify the individual contribution to bioturbation from each of the species present in the study area.

\section{Study area}

The study area (Fig. 1) is located in the northern and central part of the Venice Lagoon. Within this area four sites were selected (Industrial area: Site E1, Campalto area: site E, Giudecca area: site E14, and Palude di Cona: site G), each located at increasing distances from the industrial zone which is believed to be the main source of pollutants which contaminate the lagoon sediments.

The more distant site $(G)$ is located at a depth of $0.5 \mathrm{~m}$ (Zonta et al., 1994) in the central part of the Palude di Cona. This is a typical shallow water environment with estuarine characteristics that receives the discharge from the Dese River, one of the main freshwater inputs to the lagoon. The Campalto area (site E), also at a depth of $0.5 \mathrm{~m}$, is located between the town of Venice and the mainland. This area is crossed by many canals, which drain the last stages of the low tide (Frignani et al., 1997), and it is characterized by a silty-clay sediment which has a high content of anthropogenic heavy metals and organic microcontaminants (Frignani et al., 2000). Site E1, $1 \mathrm{~m}$ deep, is located close to the 1st Industrial Area of Porto Marghera, in front of the Isola delle Tresse. Marchini and Marchini (2006) and Sconfietti et al. (2003) provided a general subdivision of the Venise lagoon into ecological sectors based on macrobenthic assemblages obtained in 1993. Following this subdivision, stations $\mathrm{E}$ and $\mathrm{E} 1$ are located in the "Calm eutrophic" sector that represents the inner lagoon environment with poor water renewal, high nutrient content, presence of typical lagoon species and scarcity of other species. Site E14 belongs to the Giudecca mud flat, very close to the city of Venice and is included in the "Rough eutrophic" ecological sector characterised by the presence of both euryecious and lagoon species.

\section{Experimental design and analytical techniques}

The method used to quantify bioturbation is based on the use of particulate conservative tracers, called luminophores (Mahaut and Graf, 1987; Gerino, 1990; Gerino et al., 1994, 1998). These are dyed natural sediment particles that fluoresce under UV light, allowing them to be identified and counted in sediment samples. Particles of two colours, pink (63-125 $\mu \mathrm{m})$ and green $(125-350 \mu \mathrm{m})$, were used in order to obtain a more accurate estimate of the total sediment fluxes.

Experiments were carried out in autumn 1998 (at sites G and E) and in spring 1999 (at sites G, E1, E14). At each experimental site, 3 open PVC tubes $(25 \mathrm{~cm}$ long and $12.2 \mathrm{~cm}$ in diameter) were inserted into the sediment by divers. A frozen mud cake, containing the tracer, was set at the sediment surface, thus simulating a pulse input. The tracer cake $0.5 \mathrm{~cm}$ thick, $11 \mathrm{~cm}$ diameter) was prepared earlier with a mixture of surface sediment from the study site and $1 \mathrm{~g}$ of both the pink and green luminophores. To quantify nonbiological disturbance during the experiments, one control core with defaunated sediment was dug into the sediment and incubated along with experimental cores at each site. Defaunation was carried out by freezing and homogenizing 


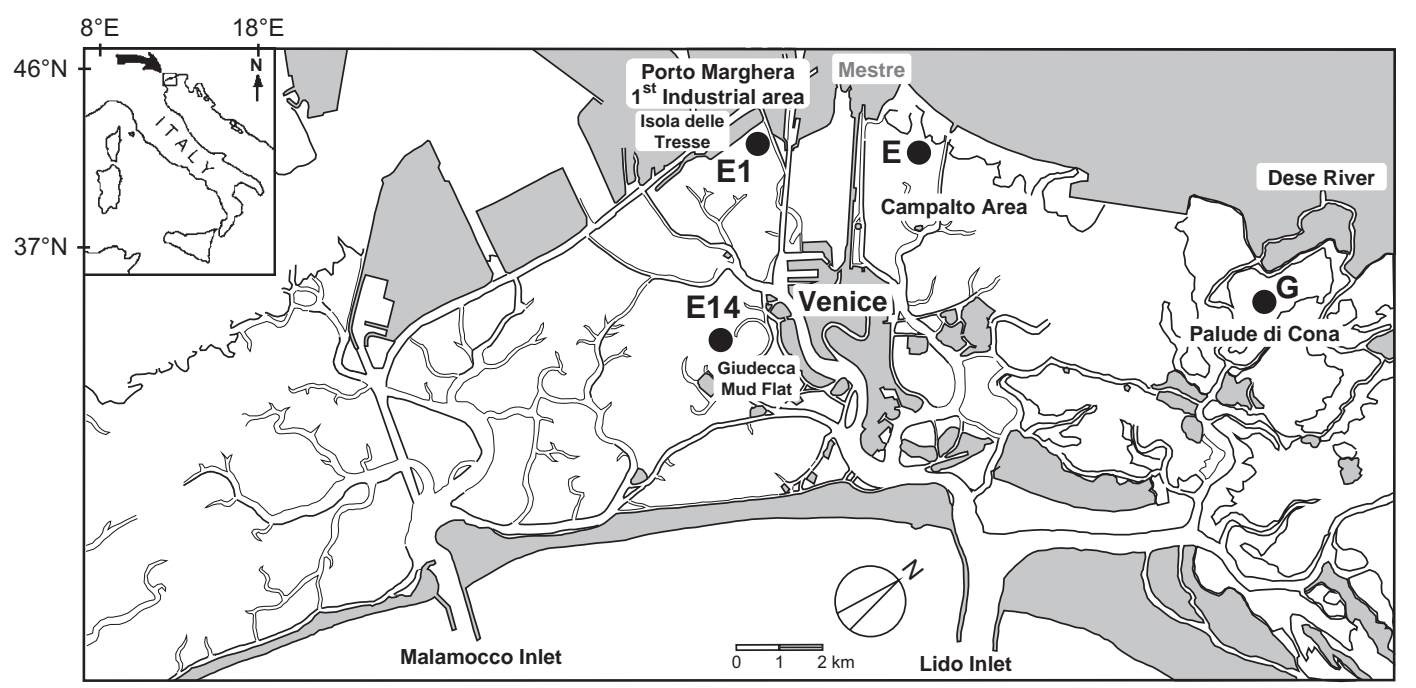

Fig. 1 - Study area and experimental sites.

sediment that had previously been collected at the same experimental site. The control sediment was not poisoned so as to avoid contamination of the lagoon and to minimize risks to the health of the people carrying out the experiments.

The tubes were carefully recovered from the study sites after a period of 15 days in autumn and 21 days in spring, and were quickly transferred to the laboratory. The sediment cores were sectioned at $0.5,1,2,3,4,5,6,8,10,12,15$, and $20 \mathrm{~cm}$ depth. Each section was wet sieved in order to remove both macrofauna and larger particles and then was allowed to settle for sediment retrieval. Two subsamples of $0.15 \mathrm{~g}$ dry weight were selected from each section of sediment which had previously been lyophilised and homogenized.

The total number of luminophores of each colour was counted in each subsample under UV light with a $25 \times$ microscope Zeiss mod. Axioplan. Luminophore counts were converted into weight units of tracer using the specific weight of the luminophores. The mean total luminophore concentration $\left(\mathrm{g} \mathrm{cm}^{-3}\right)$ in each section was estimated using sediment dry bulk density and summing the two components (pink and green). For comparison purposes, the tracer concentration in each section was normalized using the inventory for the entire core.

Macrobenthic composition at each site was determined from three (autumn) or four (spring) box cores $\left(153 \mathrm{~cm}^{2}\right.$ surface). The sediment was sieved through a series of sieves, with a minimum mesh of $0.5 \mathrm{~mm}$. The organisms were preserved using a formaline solution (4\%) prior to their identification, when possible, at the species level. Even more meaningful data were obtained by counting the organisms found in the test tubes.

\section{Results}

\subsection{Luminophores depth distributions}

In the control cores, the luminophores mainly remained at the surface, but in some cases downward migration had occurred in the top $2 \mathrm{~cm}$. Since macrofauna was found in these control cores at the end of the experiment, the displacement of the tracers in these cores has been attributed to a colonization of the defaunated sediment during in situ core incubation.

The tracer vertical distributions (Fig. 2) in the experimental cores with in situ macrofauna show evidence of luminophores penetration. The three replicate profiles obtained at the same site show quite different shapes. Multiple tracer peaks can be seen at different depths in the subsurface zone. For example, the autumn profiles at site $G(G(a))$ show an average penetration of $8 \pm 3 \mathrm{~cm}$ (median \pm range of variation, $n=3$ ), with the highest concentration close to the surface. $G(a)_{1}$ shows three well defined subsurface peaks, whereas tracer accumulations are less distinct and closer to the surface in $G(a)_{2}$ and $G(a)_{3}$ profiles (Fig. 2). In other cores, such as all E14(s) cores, E1(s) $)_{3}, G(s)_{1}$ and $\mathrm{G}(\mathrm{s})_{3}$ the maximum concentration at the end of the experiment was no longer located at the sediment surface, but immediately below. These patterns suggest non-local transport, and since this feature was not encountered in any of the corresponding control cores, this vertical transport was attributed to biological activity.

\subsection{Macrofauna}

Table 1 reports the mean densities (mean $\pm \mathrm{SE}$ ) of total macrobenthic species collected with the box cores in autumn and spring. Polychaeta were the most abundant, followed by oligochaeta (not subdivided), while mollusca were scarce. Highest macro-invertebrates densities were observed at site G. Species richness does not follow the same pattern at sites E1 and E14, where larger numbers of species were found.

The subdivision into trophic-ecological groups (Fauchald and Jumars, 1979; Fig. 3) shows that surface and subsurface deposit feeders dominate the communities at all sites while filter feeders are poorly represented. For site $G$ in autumn, this subdivision accurately reflects the abundances of the surface deposit feeder polychaete Streblospio shrubsolii, the subsurface deposit feeders oligochaeta n.c. and the 
Normalized tracer concentration
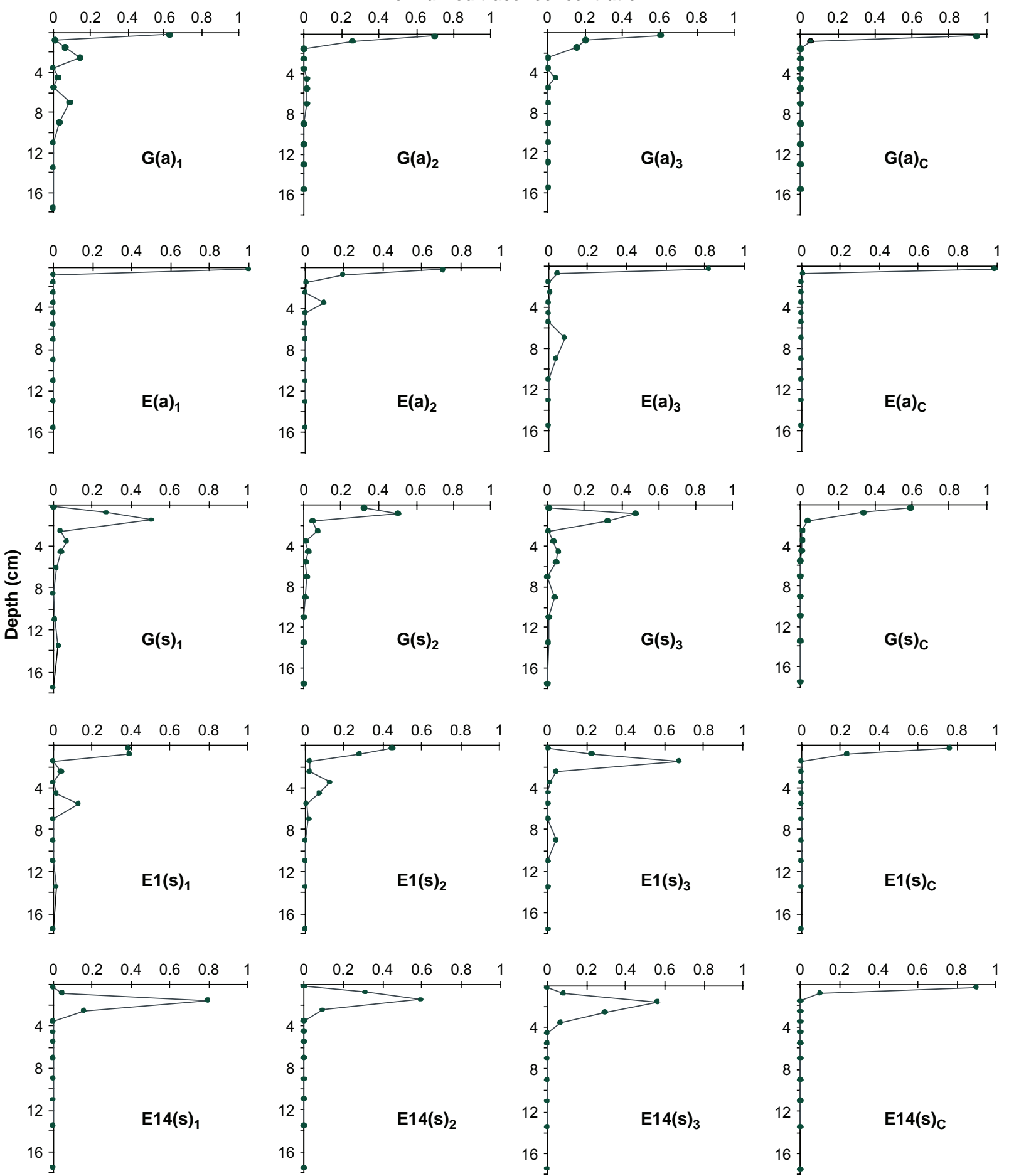

Fig. 2 - Concentration-depth profiles of luminophores in sediments of autumn (a) and spring (s) experiments. For each site, index numbers 1 to 3 indicate the profiles obtained in replicate cores with macrofauna and index " $c$ " indicates the control core. Values are normalized against total inventories.

carnivorous/omnivorous Polychaete Hediste diversicolor, respectively. In spring at site $\mathrm{G}$ the situation is similar, but the densities are lower, and some filter feeders, such as the bivalve mollusk Abra alba, were found. At site E1(s) the macrofauna is dominated by a surface deposit feeder, the polychaete Polydora ciliata. The subsurface deposit feeders, mainly
Capitela capitata, were the dominant group at site E14(s). Site E was dominated by oligochaeta. The species composition found in the experimental cores is not significantly different from the in situ community composition recovered from box cores (Tests Chi-2), except for the occurrence of one specimen of Marphysa sanguinea in experimental cores at site E1. Two 
Table 1 - Macrobenthic species densities (number of individuals $\mathrm{dm}^{-2}$ ) expressed as mean $\pm \mathrm{SE}(n=3)$ and taxa richness (number of taxa) in the box cores collected at the experimental stations. $G(a)$ and $E(a)$ are autumn samples and $G(s)$,

E1(s), E14(s) are spring samples

\begin{tabular}{|c|c|c|c|c|c|}
\hline SPECIE & $G(a)$ & $E(a)$ & $G(s)$ & E1 (s) & E14 (s) \\
\hline Hediste diversicolor & $21.33 \pm 4.26$ & $0.67 \pm 0.33$ & $14.50 \pm 1.19$ & $1.50 \pm 0.88$ & $0.25 \pm 0.00$ \\
\hline Streblospio shrubsolii & $25.00 \pm 6.11$ & $0.33 \pm 0.33$ & $14.00 \pm 4.36$ & $4.75 \pm 4.04$ & $4.00 \pm 1.54$ \\
\hline Polydora ciliata & - & - & - & $18.25 \pm 1.45$ & $1.50 \pm 0.67$ \\
\hline Capitella capitata & - & - & $0.25 \pm 0.25$ & $4.50 \pm 1.20$ & $19.75 \pm 3.00$ \\
\hline Spio decoratus & - & - & - & $0.75 \pm 0.33$ & $0.25 \pm 0.33$ \\
\hline Cirratulidae n.c. juv & - & - & - & $0.25 \pm 0.33$ & $0.75 \pm 0.00$ \\
\hline Cirrophorus furcatus & - & - & - & $0.75 \pm 1.00$ & - \\
\hline Glycera alba & - & - & - & - & $0.25 \pm 0.33$ \\
\hline Oligochaeta n.c. & $4.33 \pm 1.45$ & $3.33 \pm 1.76$ & $1.00 \pm 0.41$ & $3.25 \pm 0.67$ & $1.00 \pm 0.33$ \\
\hline Cyclope neritea & - & $0.33 \pm 0.33$ & - & - & - \\
\hline Harpacticoïdes & $4.33 \pm 2.33$ & $0.33 \pm 0.33$ & - & - & - \\
\hline Abra alba & - & - & $0.75 \pm 0.48$ & $0.25 \pm 0.00$ & - \\
\hline Venerupis aurea & - & - & - & $0.50 \pm 0.33$ & $0.25 \pm 0.33$ \\
\hline Nematode & - & - & - & - & $0.55 \pm 0.33$ \\
\hline Total densities & $55.0 \pm 10.97$ & $5.0 \pm 2.3$ & $30.5 \pm 3.6$ & $36.0 \pm 6.4$ & $28.5 \pm 1.15$ \\
\hline Richness & 4 & 5 & 5 & 10 & 10 \\
\hline
\end{tabular}

species (Cirrophorus furcatus and Glycera alba) identified in the box cores were absent in the experimental cores.

\section{Discussion}

\section{1. $\quad$ Mixing modes}

When the tracer distribution shows maximum concentration at the surface, followed by an exponential decrease with depth, the pattern is typical of a biodiffusive mixing (Goldberg and Koide, 1962; Guinasso and Schink, 1975; Cochran, 1985; Wheatcroft et al., 1990). This mixing is caused by organisms that move sediment particles in a random manner over short distances.

On the other hand, the subsurficial peaks that are generated by vertical displacement of the tracers to depth may be caused by two independent processes: bioadvection, a part of the conveying processes (Fisher et al., 1980), and regeneration (Boudreau, 1986; Gardner et al., 1987).

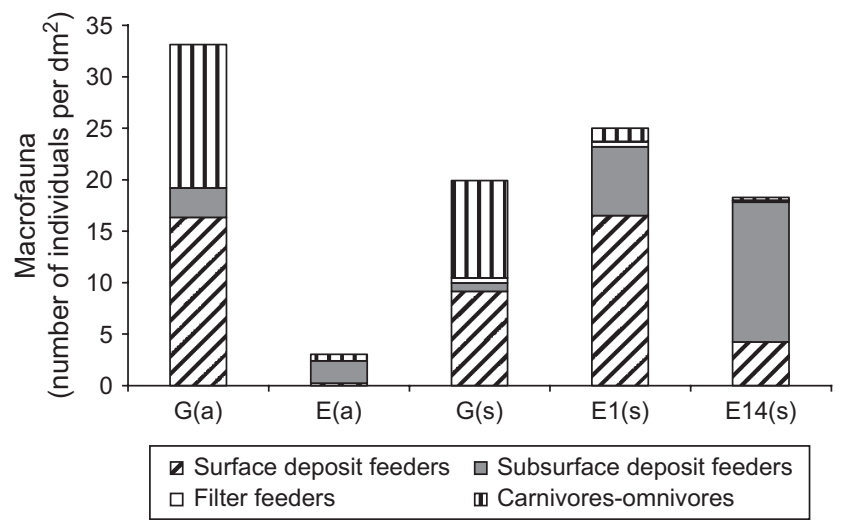

Fig. 3 - Average densities of macrofauna at each station, and repartition in trophic-ecological groups. Values are number of individuals per $\mathrm{dm}^{2}$.
Since all conveyors supply new sediment to the sediment surface, the superficial tracer input must be shifted downwards, resulting in a single peak in the subsurface sediment. This single peak will migrate deeper and deeper over the duration of the whole experiment. This burial process involves the tracer input and all the sediment from the surface to the lower limit of the conveyor's ingestion zone. Therefore, when several tracer accumulations are displayed in a single profile, regeneration is most probably involved in the burial process with downward non-local transport at depth below the upper bioadvective processes. Regeneration effects are only recorded when the tracer's input is still present at the sediment surface. Furthermore, the depth at which surface sediment accumulate by regeneration may remain constant with time. However, in contrast to bioadvective effects, regeneration may operate at different depths at the same time and several peaks in the same core may be created by regeneration in addition to those caused by bioadvection.

Essentially, when two or three subsurficial peaks are present in the subsurface sediment, with a low or zero concentration in the upper level, the upper accumulation is attributed to both the effects of conveyor and biodiffusion processes while other deeper tracer accumulation below is interpreted as regeneration effects. When tracers accumulate in the subsurface sediment and a maximum concentration still remains at the sediment surface, it may be assumed that bioadvection has not occurred in the core and deep tracer accumulations are caused by regeneration. In all cores collected from site E14, only one peak appears in the sediment column and macrofauna is dominated by the subsurface deposit feeders Capitela capitata. This species is known as a subsurface deposit feeder (Salen-Picard et al., 1994) and the tracer migration at this site should be attributed to bioadvection.

It is worth mentioning that these different types of mixing could be identified only in virtue of the short duration of the experiment. Fisher et al. (1980), found that pulse input stops downward migration driven by the conveyor belt feeding effects when it reaches the lower limit of the ingestion zone of food and sediment. The time called $\tau$ in here, required for 
the tracer pulse to migrate from the surface to the ingestion zone, corresponds to the ratio between the lower limit depth and the advective velocity. Later the tracer as well as the bulk sediment is transported again up to the surface through the guts of organisms. This process generates a second small input of tracer at the surface, which in turn can migrate downward. The cycle may be repeated for an infinite number of times and the effect is a progressive homogenization of the concentration within the mixed layer with the increasing duration of the experiment (François, 1999). The inclusion of this latter cycle, therefore, is a critical factor for the resolution of the different processes as up until now, research has focused on the estimation of the long-term combined effect of different mixing modes through activity-depth profiles of radiotracers and biodiffusive models (e.g. Cochran, 1985).

\subsection{Bioturbation coefficients}

In order to estimate bioturbation parameters, the profiles were simulated using the bioadvection-biodiffusion-non-local model in non-steady state conditions. The model was set by adding a non-local component (Boudreau, 1997) to the regular "diffusion-advection" model (Officer and Lynch, 1982; Gerino et al., 1994, 1998) so as to take into account regeneration processes. Since experimental time is relatively short compared to advection velocities, and because the larger tracer concentrations remain very close to the surface, it is assumed that the initial tracer impulse has never migrated downward to the lower limit of the ingestion zone via bioadvection processes. In this case the conveying process is limited to its bioadvective component.

Regeneration is described as a symmetric non-local mixing (Boudreau, 1997), with the same fraction of material exchanged between the surface and the regeneration zone $\left(z_{1}-z_{2}\right)$ in the downward direction. This type of non-local mixing is modeled such as a removal function, which determines the fraction of tracer removed from the surface within the particle collection zone and a regeneration function that simulates the arrival of this material in the deposition zone. Since the experiments were carried out over a very short period of time and advection was not recorded in the control cores, the sedimentation rate is not taken into account in the model. The basic equation is:

$\frac{\partial C(z, t)}{\partial t}=D_{b} \frac{\partial^{2} C(z, t)}{\partial z^{2}}-W \frac{\partial C(z, t)}{\partial z}+K(z, t)-R(z, t)$

where $C(z, t)$ is the normalized tracer concentration, $t$ is the time (years), $z(\mathrm{~cm})$ is the depth positive downward, $D_{b}$ is the biodiffusive mixing rate $\left(\mathrm{cm}^{2} \mathrm{y}^{-1}\right), \mathrm{W}$ is the bioadvective transport rate $\left(\mathrm{cm} \mathrm{y}^{-1}\right), R$ is the removal function that determines the fraction of tracer removed from the surface and transferred to depth due to regeneration $\left(\mathrm{y}^{-1}\right)$, and $\mathrm{K}\left(\mathrm{y}^{-1}\right)$ is the regeneration function that simulates the deposition of tracer removed from the surface sediment layer and regenerated between $z_{1}$ and $z_{2}$.

In this case, $\tau$ was introduced as the time when the tracer input is still available in the top $0.5 \mathrm{~cm}$ of surface sediment to supply non-local transport, $z_{1}$ and $z_{2}$ are the upper and lower limits of the regeneration zone, respectively, and Ke is a constant parameter $\left(\mathrm{y}^{-1}\right)$ estimated from the model.
Therefore:

$R(z, t)=\left\{\begin{array}{l}K(z, t) \frac{z_{2}-z_{1}}{0.5} \text { for } z \leq 0.5 \text { and } t<\tau \\ 0 \text { for } z>0.5 \text { or } t \geq \tau\end{array}\right.$

$K(z, t)=\left\{\begin{array}{l}\text { Ke for } z \in\left[z_{1}, z_{2}\right] \\ 0 \text { for } z \notin\left[z_{1}, z_{2}\right]\end{array}\right.$

Model initial conditions:

$C(z, t=0)=1$ for $z \in[0,0.5]$

$C(\mathrm{z}, \mathrm{t}=0)=0$ for $\mathrm{z}>0.5$

Model boundary conditions indicate that tracer concentrations are null when depth tends to infinite. According to the second condition, it does not exist tracer and sediment fluxes at the water sediment interface $(z=0)$ during the experiment.

$C(z \rightarrow+\infty, t)=0$

$\left.W C_{(z=0, t)}-D_{b} \frac{\partial C}{\partial z}\right]_{z=0, t}=0$

An analytical solution is provided by Officer and Lynch (1982):

$$
\begin{aligned}
C(z, t)= & \frac{1}{\pi D_{b} t} \exp \left[-\frac{(z-W t)^{2}}{4 D_{b} t}\right]-\frac{W}{2 D_{b}} \exp \left(\frac{W z}{2 D_{b}}\right) \operatorname{erfc} \frac{z+W t}{\sqrt{4 D_{b} t}} \\
& - \text { Ret }+ \text { Ket }
\end{aligned}
$$

with

$\mathrm{Re}=\mathrm{Ke} \frac{\mathrm{z}_{2}-\mathrm{z}_{1}}{0.5}$

The quantification of non-local transport from normal tracer profiles provides $K$ and $R$ parameters in $y^{-1}$. To estimate sediment removal expressed as a quantity per surface unit per time $\left(\mathrm{g} \mathrm{cm}^{-2} \mathrm{y}^{-1}\right)$, Eq. (2) is used. The non-local transport is thus quantified by a flux of sediment 'removed from the surface' called Removed Sediment RS and measured in $\mathrm{g} \mathrm{cm}^{-2} \mathrm{y}^{-1}$. Knowing that sediment was removed from a marked mud cake with a thickness of $0.5 \mathrm{~cm}$, surface $S$ $\left(\mathrm{cm}^{2}\right)$, density $\mathrm{d}\left(\mathrm{g} \mathrm{cm}^{-3}\right)$ and volume $\mathrm{V}\left(\mathrm{cm}^{3}\right)$, RS can be expressed as a function of $\mathrm{Ke}\left(\mathrm{y}^{-1}\right)$ as follows:

$\mathrm{RS}=\mathrm{Ke}(\mathrm{V} / \mathrm{S}) \mathrm{d}$

The model allows the calculation of the theoretical tracer concentration, given suitable values of the parameters $D_{b}, W, z_{1}$, $z_{2}, \mathrm{Ke}$ and RS. These parameters are selected from profiles that produce the best fit with the experimental data using the least square method and Excel software. The best fit of core $\mathrm{G}(\mathrm{a})_{3}$ is shown as an example in Fig. 4.

Table 2 gives the mean mixing coefficients $D_{\mathrm{b}}, \mathrm{W}$ and Ke, along with the depth of the upper and lower limits of regeneration $z_{1}$ and $z_{2}$, estimated in the 3 replicated in situ experiments (mean $\pm(\sigma / \sqrt{n}), n=3$ ) for each site along with the same parameters measured in the control cores. Large differences in mixing coefficients at one site can be attributed to horizontal variability of the benthic community. This intrasite heterogeneity of tracer profiles demonstrates that at least 3 replicated measurements are required to estimate major bioturbation types and their intensities at one site.

Since vertical tracer distributions in the control cores do not exhibit significant burial of tracer deeper than $2 \mathrm{~cm}$, and maximum concentrations remain at the sediment surface, it can be assumed that sedimentation is absent in all experimental 


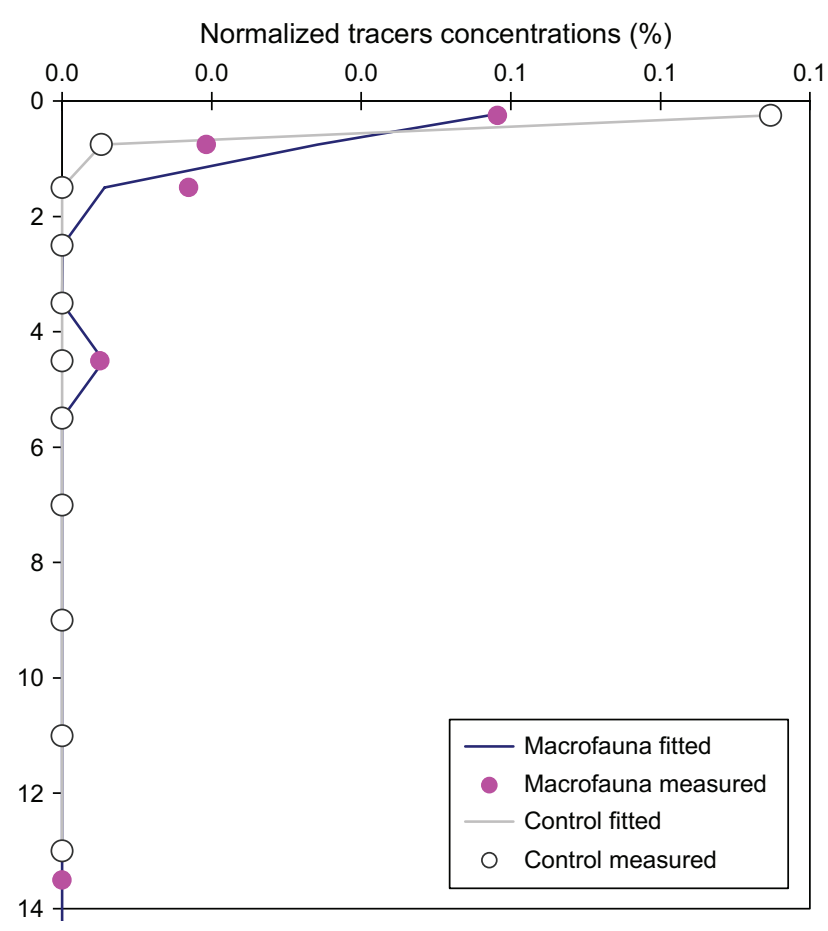

Fig. 4 - Best fit, using the least squares method, of the tracer concentrations $\mathrm{G}(\mathrm{a})_{3}$ measured with in situ invertebrate community in experimental core at site $G$ during autumn 1998 (Macrofauna measured) with the model output profile (Macrofauna fitted). Estimated biodiffusion coefficient $D_{b}\left(\mathrm{~cm}^{2} \mathrm{y}^{-1}\right)$ is 6.0 , vertical transport rates $W\left(\mathrm{~cm} \mathrm{y}^{-1}\right)$ is $=0.5$ and regeneration $\mathrm{Ke}$ $\left(y^{-1}\right)=7.3$. Best fit of the tracer concentrations in the corresponding control core without fauna at site G during autumn 1998 (Control measured) with model output profile (Control fitted). Estimated coefficients in the control core are $D_{\mathrm{b}}\left(\mathrm{cm}^{2} \mathrm{y}^{-1}\right)=1.1, \mathrm{~W}\left(\mathrm{~cm} \mathrm{y}^{-1}\right)=0.3$ and $\mathrm{Ke}\left(\mathrm{y}^{-1}\right)=0$.

cores, and that tracer dispersion in the control cores is assumed to be mostly driven by hydrodynamics. The application of a diffusive model on these tracer profiles provides an upper estimate of the physical disturbance. The overestimate is due to the superimposition of biomixing effects in the control cores due to the low recolonisation occurred during the experimental period.

The distinct patterns of luminophore distributions in experimental cores with initial invertebrate communities are attributed to macrofauna effects in addition to physical disturbance. Bulk transport rates estimated in these cores by model fitting, and intensities of physical transport are accounted for in the assessment of the net bioturbation rates by substracting control transport rates from bulk transport rates. This correction is only applied to biodiffusive rates because the other mixing rates in the controls are not significant and also because when the physical rate is higher than the measured biodiffusion, the net coefficient is assumed to be nil. In this way, the net $D_{\mathrm{b}}$ coefficient was estimated as $2.03 \pm 1.68$ (mean $\pm \mathrm{SE}, n=3$ ) and $0.0 \pm 0.0$ at site $\mathrm{G}$ in autumn and spring respectively, $0.83 \pm 0.64$ at site $\mathrm{E}, 1.27 \pm 0.92$ at site $\mathrm{E} 1$, and $1.28 \pm 0.43 \mathrm{~cm}^{2} \mathrm{y}^{-1}$ at site E14. Total $\mathrm{W}$ ranges from
$0.12 \pm 0.09$ (E) to $27.41 \pm 2.46 \mathrm{~cm} \mathrm{y}^{-1}$ (E14) while total RS ranges from $0.00 \pm 0.00$ to $5.47 \pm 1.09 \mathrm{~g} \mathrm{~cm}^{3} \mathrm{y}^{-1}$ (E1 and E14).

Biodiffusion and bioadvection rates are of the same order of magnitude as those reported in the literature and obtained using the same method by Gerino et al. $(1994,1998)$ for the Rhônes River estuary and Long Island Sound where sediment granulometries are similar to those of the Venice Lagoon. One previous measurement of bioturbation in Venice lagoon was made on the northern part of the Paluda di Cona using a $\mathrm{Be}^{7}$ activity-depth profile in March, 1992 from which a $D_{\mathrm{b}}$ value of $3.73 \mathrm{~cm}^{2} \mathrm{y}^{-1}$ was estimated (Frignani et al., 1997). Since the $\mathrm{Be}^{7}$ depth distribution results from both physical and biological mixing, this earlier $D_{\mathrm{b}}$ value is comparable with the bulk biodiffusion mixing rate of $3.9 \mathrm{~cm}^{2} \mathrm{y}^{-1}$ obtained at site $\mathrm{G}$ in spring.

Burial velocities have been demonstrated to be clearly dependent on temperature and conveyor density (Davis, 1974; Gerino et al., 1998). Measurements obtained from Tubificid oligochaetes, which are known to be the very active conveyors, allowed Davis (1974) to estimate bioadvection velocities as ranging between 3.7 and $170 \mathrm{~cm} \mathrm{y}^{-1}$ for 1000 individuals $\mathrm{dm}^{-2}$ when temperature was $0-10^{\circ} \mathrm{C}$. Assuming a direct relationship between conveyor densities and bioadvection velocities, the known conveyors Capitella capitata and Oligochaeta present with densities of 20 ind. $\mathrm{dm}^{-2}$ at site E14 should yield bioadvection rates 50 times lower in the Venice Lagoon. The low number of conveyor individuals in the lagoon sediment may be attributed to factors such as sediment grain size, low organic matter content and the presence of contaminants. No direct measurements of downward non-local transport for similar environments can be found in the literature, therefore no comparison is possible with the estimates of regeneration from this present investigation.

\subsection{Variability of mixing coefficients}

On the scale of the Venice lagoon, variations in the type of biological sediment transport between sites can be explained by the spatial and temporal heterogeneity in the qualitative and quantitative compositions of benthic communities. No distinct trends could be found for biodiffusion, bioadvection and regeneration rates with respect to the distance from the industrial zone.

Probabilities and degrees of freedom of the site and season effects as sources of variation of mixing coefficients were estimated by non-parametric tests. Site effect was tested using all sites measurements without control cores data (Kruskal-Wallis test); season effect was tested with site G coefficients without control cores data (Mann-Whitney test).

Results from these tests showed that biodiffusion coefficients $\left(D_{\mathrm{b}}\right)$ and regeneration $(\mathrm{Ke})$ did not vary significantly with time and space at the studied sites. Consequently, the average mixing rate is estimated using results from all sites in the Venice Lagoon for both seasons, and values of $D_{b}$ and Ke (mean $\pm \sigma / \sqrt{n}, n=15$ ), which represent the average rates in the lagoon, were estimated to be $2.19 \pm 0.91 \mathrm{~cm}^{2} \mathrm{y}^{-1}$ and to $11.43 \pm 5.34 \mathrm{y}^{-1}$, respectively. The same season and sites factors, demonstrate significant effects on bioadvection coefficients (W) in identical conditions. The variation in the bioadvective component noted among sites is attributed to 
Table 2 - Bioturbation coefficients and removed sediment values from modeling. Mean \pm SE of mixing coefficients $(n=3)$ represent average coefficients for each season ( $\mathrm{a}=$ autumn and $\mathrm{s}=$ spring), calculated using the biodiffusion-

bioadvection and non-local model applied on the experimental profiles with benthic community. Physical mixing

rates as measured in control cores without macrofauna are also included in this table. $D_{b}\left(\mathrm{~cm}^{2} y^{-1}\right)=b i o d i f f u s i o n ; W$

$\left(\mathrm{cm} \mathrm{y}^{-1}\right)=$ bioadvection; $\mathrm{Ke}\left(\mathrm{y}^{-1}\right)=$ sediment input due to non-local transport; $\mathrm{z}_{1}, \mathrm{z}_{2}(\mathrm{~cm})=$ depth of upper and lower

limits of non-local zone; RS ( $\left.\mathrm{g} \mathrm{cm}^{-2} \mathrm{y}^{-1}\right)$ = removed sediment from the surface layer by non-local transport, expressed per unit area of sediment-water interface

\begin{tabular}{lcccccc} 
Site & $D_{\mathrm{b}}\left(\mathrm{cm}^{2} \mathrm{y}^{-1}\right)$ & $\mathrm{W}\left(\mathrm{cm} \mathrm{y}^{-1}\right)$ & $\mathrm{Ke}\left(\mathrm{y}^{-1}\right)$ & $\mathrm{z}_{1}(\mathrm{~cm})$ & $z_{2}(\mathrm{~cm})$ & $R S\left(\mathrm{~cm}^{-2} \mathrm{y}^{-1}\right)$ \\
\hline $\mathrm{G}(\mathrm{a})$ & $3.13 \pm 1.68$ & $00.23 \pm 0.15$ & $11.20 \pm 3.90$ & $3.00 \pm 1.00$ & $7.00 \pm 1.15$ & $5.11 \pm 2.92$ \\
$\mathrm{G}(\mathrm{a})$ control & 1.10 & 0.30 & 0.00 & - & - & - \\
E(a) & $1.53 \pm 0.64$ & $00.12 \pm 0.09$ & $12.17 \pm 7.40$ & $3.00 \pm 1.73$ & $4.67 \pm 2.91$ & $3.65 \pm 2.22$ \\
E(a) control & 0.70 & 0.00 & 0.00 & - & - & - \\
G(s) & $0.87 \pm 0.20$ & $15.50 \pm 30.44$ & $18.25 \pm 3.65$ & $2.33 \pm 0.33$ & $7.33 \pm 1.45$ & $5.47 \pm 1.09$ \\
G(s) control & 2.60 & 0.00 & 0.00 & - & - & - \\
E1(s) & $3.17 \pm 0.92$ & $10.33 \pm 6.73$ & $15.55 \pm 6.01$ & $4.33 \pm 1.86$ & $7.00 \pm 1.53$ & $4.66 \pm 1.80$ \\
E1(s) control & 1.90 & 0.00 & 0.00 & - & - & - \\
E14(s) & $2.27 \pm 0.43$ & $27.41 \pm 2.46$ & $00.00 \pm 0.00$ & - & - & $00.00 \pm 0.00$ \\
E14(s) control & 0.90 & 0.00 & 0.00 & - & - & - \\
\hline
\end{tabular}

the composition of benthic communities which is a function of site characteristics, level of disturbance and time of the experiment. Furthermore, bioadvection velocities show significant seasonal differences at site $G$ that are likely to be related to temperature changes. Bioadvection is higher in the spring time than in autumn, probably due to appearance of Capitella capitata (Table 1). Temporal evolution of macrofauna community composition with temperature is considered as the major source of bioadvection velocity variation.

\subsection{Relationship between benthic populations and bioturbation}

Benthic communities described in these studies are related to environmental characteristics of the lagoon in 1998 and 1999. A first assessment by Laubier (1962) had shown the presence of 124 species only for the polychetes group in the eutrophic sectors of stations E, E1 and E14. The very low community richness at the time of this study, compared to previous data, account for a large species richness erosion over time, probably due to the increase of anthropogenic effects (nutrients and pollutant discharges) on environmental lagoon conditions. No early data were available to compare with present estuarine sector communities. Later investigations of the same communities in 2002 (D. Prevedelli, unpublished data; Magistrato alle Acque di Venezia, 2004) demonstrated a general trend toward a recovery (species abundances between 18 and 25 at all study sites) while densities remained constant. However, pollution bioindicator species like Capitella are still present with large densities in the communities. Since relationships between community structures (density and richness) and bioturbation rates are not yet fully understood, because of the complexity and variability of the biological response, it remains very difficult in this context to predict any future evolution of bioturbation rates and modes.

An examination of the relationships between species densities in the experimental units and the corresponding mixing coefficients permits both the identification of the species that are most likely contributing to each biological transport mechanisms and a quantitative assessment of the relative contribution of these species to the different mixing intensities.
Since several species may contribute to each type of mixing process, and because relationships between organism densities and bioturbation effects may well be described by linear functions (Emerson et al., 2001), a multiple linear regression model was applied using Minitab software.

To carry out statistical analyses of macrofaunal effect, all the bioturbation coefficients obtained from cores with in situ benthic communities and coefficients recorded in control cores were considered as dependant variables, whereas the species densities were used as sources of variations.

The species densities in control cores at the end of the experiment were not equal to zero (Table 1) and since the macrofaunal composition in controls was different from what was found in the other experimental cores at the end of the experiment, data from these control cores served to enlarge the range of density gradients and coefficients found in this test. A forward selection procedure was run for each mixing type starting with all species as contributor variables. The selection of the smaller best sub set of variables was performed using adjusted $R^{2}$ criteria and knowledge of the species behaviour. The $\beta$ coefficients obtained with this combination of species for each of the transport coefficients are listed in Table 3 , together with the probability of the null hypotheses $\left(H_{0}: \beta_{i}=0\right)$. Species of which only one individual was identified in the set of experimental cores (i.e. Marphysa sanguinea and Venerupis aurea), were removed from the independent variables, even though the latter is known to cause significant biodiffusive mixing when measured in monospecific microcosms (François et al., 1999).

According to this regression procedure, only those species with positive and significant partial regression coefficients among the group of species that contribute to one type of mixing may increase the value of the related dependent mixing coefficient. Those species with significant negative coefficients are likely to develop adverse interactions with other species thus contributing to a decrease in the related mixing rate. This type of negative relationship is often referred as amensalism.

The polychaetes Paraonidae Spio decoratus, and copepods Harpacticoïdes Cyclope neritea have been identified as macrobenthic species that contribute to biodiffusion. Although there is scarce literature on reworking activities of Spio decoratus or 
Table 3 - Partial regression coefficients and the related probabilities $\left(H_{0}=\beta_{i}=0\right)$ obtained with the 3 multiple linear

regression models: $\mathbf{y}_{\mathbf{i}}=\sum_{\mathbf{j}}^{1} \beta_{\mathrm{j}} \mathbf{x}_{\mathrm{i}}+$ Cte with $\mathbf{j}=3$ to 6 . Each regression coefficient gives the contribution of a species to the

total theoretical variation of a mixing coefficient. For each mixing coefficient, $D_{\mathrm{b}}, \mathrm{W}$, and $\mathrm{K}$, a model was constructed using a forward selection procedure of the predictor variables with adjusted $R^{2}$ as selection criteria. Bold numbers indicate significant $\beta$ values $(p<0.05)$

\begin{tabular}{|c|c|c|c|c|c|c|}
\hline \multirow[t]{2}{*}{ Species } & \multicolumn{2}{|c|}{$D_{\mathrm{b}}$ model } & \multicolumn{2}{|c|}{ W model } & \multicolumn{2}{|c|}{ Ke model } \\
\hline & $\beta_{i}$ & $p$ & $\beta_{i}$ & $p$ & $\beta_{i}$ & $p$ \\
\hline Constant term & 1.60 & 0.000 & 1.62 & 0.536 & -3.37 & 0.169 \\
\hline Hediste diversicolor & 0.03 & 0.183 & & & 0.31 & 0.001 \\
\hline Streblospio shrubsolii & -0.05 & 0.022 & 0.23 & 0.022 & & \\
\hline Spio decoratus & 1.63 & 0.001 & -4.16 & 0.177 & & \\
\hline Polydora ciliata & & & & & 1.04 & 0.001 \\
\hline Cirratulidae juv. undt. & -1.82 & 0.011 & 11.01 & 0.033 & & \\
\hline Capitella capitata & -0.06 & 0.062 & 0.56 & 0.026 & & \\
\hline Oligochaeta undt. & & & & & 0.43 & 0.001 \\
\hline Cyclope neritea & 0.12 & 0.001 & -0.53 & 0.034 & & \\
\hline Abra alba & & & 7.76 & 0.110 & & \\
\hline Nematoda & & & & & & \\
\hline Adjusted $R^{2}$ & $60.6 \%$ & & $56.2 \%$ & & $64.9 \%$ & \\
\hline$F$ & 5.88 & 0.004 & 5.07 & 0.007 & 12.72 & 0.000 \\
\hline
\end{tabular}

meiofauna including copepods, the potential of meiofauna and the Paraonidae species to participate in benthic bioturbation may however be underestimated merely because few studies directly measured their effect in relation to their abundances (Hakenkamp and Morin, 2000; Tita et al., 2001). The reworking activity of Cyclope neritea is mentioned in another Mediterranean lagoon (Koutsoubas et al., 2000). The absence of cirratulidae among the species contributing to biodiffusive mixing may be open to discussion due to direct measurement of bioturbation activity of Cirratulidae Taryx sp. in monospecific culture that confirmed the strong biodiffusive mixing produced by this class of polychaetes (Gerino, 1992). The fact that the population of Cirratulidae present in the Venice Lagoon at the time of the experiment were juveniles may explain why they did not contribute significantly to biodiffusion. The polychaetes Capitella capitata, Streblospio shrubsolii and juvenile Cirratulidae species, with a major contribution of Capitella capitata, can be related to bioadvection. The presence of Capitellidae, well known as conveyor-belt polychaetes (SalenPicard et al., 1994), confirms the coherence of our results. While there is little information about the participation of Streblospio in bioturbation activity available in the literature, most existing documents demonstrate the high tolerance of this species to PAHs, due to its ability to metabolise organic xenobiotics (Chandler et al., 1997; Ferguson and Chandler, 1998). Organic contaminants reach significant concentrations at some sites in the Venice lagoon (e.g. E1 and E; Frignani et al., 2000, 2001, 2005) so that the bioturbation by Streblospio may be explained by both its resistance in this environment and the persistence of its activity. The regression analysis indicates that regeneration processes are mainly carried out by Hediste diversicolor, in agreement with what is found in the literature. Experiments by Gerino and Stora (1991) demonstrated that the activities of nereides such as Hediste diversicolor do not imply diffusive mixing, but rather a rapid vertical flux of particles. In particular, these authors showed that there was a significant correlation between the surface area of burrows walls and the number of luminophores that reached each level down core. This indicates that such a displacement is due to the presence of large galleries of Nereis diversicolor that trap the material by means of the mucus excreted by the animals. The tracer profile at site $G$ recorded in autumn (Fig. 2) suggests that activities of this type are taking place, with tracer fluxes between $3 \pm 4.3$ and $7 \pm 5.0 \mathrm{~cm}$. This means that there is a possible intrusion into the first $12 \mathrm{~cm}$ of the sediment column, in agreement with the literature. The participation of oligochaetes in the regeneration process is significant in this analysis. Most studies of oligochaete effects refer to the tubificidae family which is well know for very intensive conveying feeding (Fisher et al., 1980; Mc Call and Tevest, 1982; Ciutat et al., 2005). However, since oligochetes were not taxonomically identified in this study, it is thought that they may group together with different species with variable effects on bioturbation. However, the actual participation of the oligochaetes in the group of species involved in regeneration in Venice lagoon should be confirmed by testing the multiple regression analysis with additional data of the same community, accompanied by oligochaete identification at the family or species level.

While the involvement of a third polychaete, Polydora ciliata, in bioturbation is not mentioned in the literature (Hill, 2000), this species occurs among those that cause regeneration in the present study. It would therefore be useful to carry out supplementary analyses that combine taxonomic identification, density counting together with bioturbation coefficients measurements in the same sediment to determine their effects.

One species, Abra alba, has no significant relationship with the measured coefficients. This filter feeder appears to have a limited impact on bioturbation with a small displacement of sediment. The polychaetes Cirrophorus furcatus and Glycera alba were not identified in any of the experimental cores and these species are not included in Table 3.

In conclusion, the major bioturbators distinguished above may be classified into functional bioturbation groups according to their participation in the different mixing processes (Gerino et al., 2003) (Table 4). One goal of this study was to test a method for the identification of bioturbation groups. The convergence of the major results of the multiple 
Table 4 - Functional Feeding Groups FFG from literature (subsurface deposit feeders = SSD, surface deposit feeders $=$ SD, filter feeders $=$ FF, carnivorous $=$ C) and bioturbation groups for each species as indicated by regression analyses and confirmed by literature ("NB" = no evidence of bioturbation effects in the present study, "_" = species not present in the experimental cores, "NC" = bioturbation effects that need confirmation with additional data)

\begin{tabular}{lll} 
Species & FFG & Bioturbation groups \\
\hline Hediste diversicolor & C & Regenerator \\
Streblospio shrubsolii & SD & NC \\
Spio decoratus & SD & Biodiffusors \\
Polydora ciliata & SD & NC \\
Cirratulidae juv. undt. & SD & NC \\
Marphysa sanguinea & SD & Biodiffusors \\
Capitella capitata & SSD & Conveyor Belt Feeder \\
Cirrophorus furcatus & SSD & - \\
Glycera alba & C & - \\
Oligochaeta undt. & SSD & NC \\
Cyclope neritea & SD & Biodiffusors \\
Abra alba & FF & NB \\
Venerupis aurea & FF & Biodiffusors \\
Nematoda & SSD & NB \\
\hline
\end{tabular}

regression analysis with current knowledge of the bioturbation process confirms the validity of the approach. In this classification strategy some organisms may belong to more than one group, but no overlap was discovered between groups within the studied community. The benthic species of the Venice lagoon also may show multiple functions over different bioturbation groups by the way of positive effects in one type of mixing and negative effects in another. In the present community Cyclope neritea illustrates this effect since it participate to increase biodiffusion and demonstrate negative effects on conveying process, probably reducing bioadvection rate. These positive or negative effects of bioturbators may be common in the benthic habitat and may significantly influence both the strength and effects of the different bioturbation processes.

\section{Conclusions}

Luminophores penetration into sediments was largely driven by the reworking activities of benthic organisms. Physical processes were much less effective in mixing sediment, as demonstrated by control cores. The short time scale of the experiments and the pulse input of tracers allowed a clear discrimination between the diffusive and non-local transport processes of the entire benthic community under in situ conditions. Non-local transports processes, identified as conveying and regeneration, dominate the biological mixing with biodiffusion rates remaining very low.

The macrobenthic communities identified at each site are clearly diversified with respect to the number of species and organisms, even though these are both very low. This diversity in the community compositions results in differences in the mode and intensity of the sediment reworking rates recorded over the lagoon. Considering all sites and seasons, $D_{\mathrm{b}}$ ranged from $0.87 \pm 0.02$ to $3.17 \pm 0.92 \mathrm{~cm}^{2} \mathrm{y}^{-1}, W$ from
$0.12 \pm 0.09$ to $27.41 \pm 2.47 \mathrm{~cm} \mathrm{y}^{-1}$ and RS from $3.65 \pm 2.22$ to $5.47 \pm 1.09 \mathrm{~g} \mathrm{~cm}^{-2} \mathrm{y}^{-1}$ (mean $\pm \mathrm{SE}, n=3$ ).

Repeated experiments at site $\mathrm{G}$ during autumn and spring conditions indicate respectively total $D_{\mathrm{b}}$ of $2.3 \pm 6.1$ and $0 \mathrm{~cm}^{2} \mathrm{y}^{-1}$ and total $\mathrm{W}$ of $0.9 \pm 2.5$ and $15.5 \pm 14.8 \mathrm{~cm} \mathrm{y}^{-1}$. This reflects a minor variability of sediment reworking by biodiffusion over two different seasons while bioadvection processes are more rapid in spring in relation with the increase of conveyor populations.

The assessment of the three major sediment mixing rates and macrobenthos compositions allowed significant correlations between species and their sediment reworking modes to be identified. The correspondence between the transport type identified for each species and the information from the literature confirms the accuracy of the estimates obtained from the regression model. In particular, it was noted that Spio decoratus and Cyclope neritea were associated with biodiffusion, whereas bioadvection was caused by Capitella capitata, Streblospio shrubsolii and juvenile Cirratullidae. Regeneration was mainly due to the activity of Hediste diversicolor.

Biodiffusion coefficients are not affected by sediment pollution gradients. Variability was observed for the conveying transport, mainly due to seasonal changes in the abundances of the species responsible for this type of bioturbation.

The future integration of bioturbation processes in mechanistic models used to describe pollutant transport processes in the sediment should provide the capability to explain changes in the downward distribution of sediment contaminants and their fluxes at the sediment-water interface.

\section{Acknowledgments}

This study, carried out within the framework of the Program 2023, was funded by the Ministry of Public Works, through the Magistrato alle Acque di Venezia and the Consorzio Venezia Nuova. 2002 macrobenthos information were obtained by Tethis on behalf of the Ministero delle Infrastrutture-Magistrato alle Acque, trough its concessionaire Consorzio Venezia Nuova. The authors wish to thank I. Ongaro, M. Colle and A. Grippaldi for the assistance in field work and S. Albertazzi for contribution to the subsampling of cores and sample treatment. K. Schwarzer provided the luminophores. This is contribution n. 1563 of the Consiglio Nazionale delle Ricerche, Istituto di Scienze Marine, Sede di Bologna, Italy.

\section{R E F E R E N C E S}

Aller, R.C., 1982. The effects of macrobenthos on chemical properties of marine sediment and overlying water. In: McCall, P.L., Tevesz, M.J.S. (Eds.), Animal-Sediment Relations. Plenum Press, New York, pp. 53-102.

Berger, W.H., Heath, G.R., 1968. Vertical mixing in pelagic sediments. Journal of Marine Research 26, 134-143.

Berner, R.A., 1980. Early Diagenesis. A Theoretical Approach. Princeton University Press, Princeton, NJ.

Boudreau, B.P., 1986. Mathematics of tracer mixing in sediments: II Non local mixing and biological conveyor-belt phenomena. American Journal of Sciences 286, 199-238. 
Boudreau, B.P., 1997. Diagenetic models and their implementation. Springer Verlag, $414 \mathrm{pp}$.

Bromley, R.G., 1990. Trace Fossils: Biology and Taphonomy. In: Special Topics in Palaeontology, 3. Unwin Hyman Ltd, London.

Ciutat, A., Gerino, M., Anschultz, P., Boudou, A., 2005. Bioturbation effects by Tubificid oligochaetes on cadmium transfer and distribution into fresh water sediments. Environmental Toxicology and Chemistry 60 (3), 237-246.

Chandler, G.T., Shipp, M.R., Donelan, T.L., 1997. Bioaccumulation, growth and larval settlement effects of sediment-associated polynuclear aromatic hydrocarbons on the estuarine polychaete, Streblospio benedicti (Webster). Journal of Experimental Marine Biology and Ecology 213 (1), 95-110.

Cochran, J.K., 1985. Particle mixing rates in sediments of the eastern equatorial Pacific: evidence from ${ }^{210} \mathrm{~Pb},{ }^{239,240} \mathrm{Pu}$ and

${ }^{137} \mathrm{Cs}$ distributions at MANOP sites. Geochimica et Cosmochimica Acta 49, 1195-1210.

Davis, R.B., 1974. Stratigraphic effects of tubificids in the profundal lake sediments. Limnology and Oceanology 19, 466-488.

Fauchald, K., Jumars, P.A., 1979. The diet of worms: a study of polychaete feeding guilds. Oceanography and Marine Biology. An Annual Review 17, 193-284.

Ferguson, P.L., Chandler, G.T., 1998. A laboratory and field comparison of sediment PAH bioaccumulation by the cosmopolitan estuarine polychaete Streblospio benedicti (Webster). Marine Environmental Research 45 (4/5), 387-401.

Fisher, J.B., Lick, W.J., McCall, P.L., Robbins, J.A., 1980. Vertical mixing of lake sediments by tubificid oligochaetes. Journal of Geophysical Research 85 (C7), 3997-4006.

François F., 1999. Mise au point d'un nouveau modèle de bioturbation pour une approche fonctionnelle du remaniement sédimentaire lié à l'activité des communautés macrobenthiques. These Docteur en Science, Université Aix Marseille II, $110 \mathrm{pp}$.

François, F., Poggiale, J.C., Durbec, J.P., Stora, G., 1997. A new approach for the modelling of sediment reworking induced by a macrobenthic community. Acta Biotheoretica 45, 295-319.

François, F., Dalègre, K., Gilbert, F., Stora, G., 1999. Variabilité spécifique à l'intérieur des groupes fonctionnels: étude du remaniement sédimentaire de deux bivalves Veneridae, Ruditapes decussatus et Venerupis aurea. Comptes Rendus Académie des Sciences Série III. Sciences de la Vie/Life Sciences 322, 339-345.

Frignani, M., Bellucci, L.G., Langone, L., Muntau, H., 1997. Metal fluxes to the sediments of the northern Venice Lagoon. Marine Chemistry 58, 275-292.

Frignani, M., Bellucci, L.G., Albertazzi, S., 2000. Progetto 2023, Inquinamento e dinamica dei sedimenti. Final Report to the "Consorzio Venezia Nuova", Venice.

Frignani, M., Bellucci, L.G., Carraro, C., Favotto, M., 2001. Accumulation of polychlorinated dibenzo-p-dioxins and dibenzofurans in sediments of the Venice Lagoon and the industrial area of Porto Marghera. Marine Pollution Bulletin 42, 544-553.

Frignani, M., Bellucci, L.G., Favotto, M., Albertazzi, S., 2005. Pollution historical trends as recorded at selected sediment sites of the Venice Lagoon. Environmental International 31, 1011-1022.

Gardner, L.R., Sharma, P., Moore, W.S., 1987. A regeneration model for the effect of bioturbation by fiddler crabs on ${ }^{210} \mathrm{~Pb}$ profiles in salt marsh sediments. Journal of Environmental Radioactivity 5, 25-36.

Gerino, M., 1990. The effect of bioturbation on particle redistribution in Mediterranean coastal sediment. Preliminary results. Hydrobiologia 207, 251-258.

Gerino, M., Stora, G., 1991. Analyse quantitative in vitro de la bioturbation induite par la Polychète Nereis diversicolor.
Comptes Rendus Académie des Sciences, Paris, Série III, Océanographie Biologique 313, 489-494.

Gerino, M., Stora, G., Durbec, J.P., 1994. Quantitative estimation of biodiffusive and bioadvective sediment mixing: in situ experimental approach. Oceanologica Acta 17 (5), 547-554.

Gerino, M., Aller, R.C., Lee, C., Cochran, J.K., Aller, J.Y., Green, M.A., Hirchberg, D., 1998. Comparison of different tracers and method used to quantify bioturbation during a spring bloom: ${ }^{234}$ Thorium, luminophores and chlorophyll a. Estuarine. Coastal and Shelf Science 46, 531-547.

Gerino, M., Stora, G., François-Carcailler, F., Gilbert, F., Poggiale, J.C., Mermillod-Blondin, F., Desrosiers, G., Vervier, P., 2003. Macroinvertebrate functional groups in freshwater and marine sediments: a common mechanistic classification. Vie et Milieu 5 (4), 221-232.

Goldberg, E.D., Koide, M., 1962. Geochronological studies of deep sea sediments by the ionium/thorium method. Geochimica and Cosmochimica Acta 26, 417-450.

Guinasso Jr., N.L., Schink, D.R., 1975. Quantitative estimates of biological mixing rates in abyssal sediments. Journal of Geophysical Research 80 (21), 3032-3043.

Hakenkamp, C.C., Morin, A., 2000. The importance of meiofauna to lotic ecosystem functioning. Freshwater Biology 44 (1), 165-175.

Hill, J.M., 2000. Polydora ciliata. A Bristleworm. Marine Life Information Network: Biology and Sensitivity Key Information Sub-program. Marine Biological Association of the United Kingdom, Plymouth.

Koutsoubas, D., Arvanitidis, C., Dounas, C., Drummond, L., 2000. Community structure and dynamics of the molluscan fauna in a Mediterranean lagoon (Gialova lagoon, SW Greece). Belgium Journal of Zoology 130, 131-138.

Laubier, L., 1962. Quelques annelides polychètes de la lagune de Venise. Description de Prionospio casperni $n$. sp. Vie et Milieu 8 (1), 123-159.

Mahaut, M.L., Graf, G., 1987. A luminophore tracer technique for bioturbation studies. Oceanologica Acta 10 (3), 323-328.

Magistrato alle Acque di Venezia, 2004. Esiti delle campagne di acquisizione dati macrofitobenthos, macrozoobenthos e meiozoobenthos. I anno. In: Nuovi interventi per la salvaguardia di Venezia. Attivita' di Monitoraggio ambientale della Laguna di venezia. Esecutivo del $2^{\circ}$ stralcio triennale (2002-2005) Mel a2. Attivita 3C.4.5.

Marchini, A., Marchini, C., 2006. A fuzzy logic model to recognise ecological sectors in the lagoon of Venice based on the benthic community. Ecological modelling 193 (1-2), 105-118.

McCall, P.L., Tevest, J.B., 1982. The effects of benthos on physical properties of freshwater sediments. In: McCall, P.L., Tevest, J.B. (Eds.), Animal-Sediment Relations. Plenum Press, NY, pp. 105-176.

Mugnai, C., Gerino, M., Frignani, M., Sauvage, S., Bellucci, L.G., 2003. Bioturbation experiments in the Venice Lagoon. Hydrobiologia 494, 245-250.

Officer, C.B., Lynch, D.R., 1982. Interpretation procedures for the determination of sediment parameters from time-dependent flux inputs. Earth and Planetary Science Letters 61, 55-62.

Rhoads, D.C., 1974. Organism-sediment relations on the muddy sea floor. Oceanography and Marine Biology: an Annual Review 12, 263-300.

Rice, D.L., 1986. Early diagenesis in bioadvective sediments: relationships between the diagenesis of beryllium-7, sediment reworking rates, and the abundance of conveyor-belt depositfeeders. Journal of Marine Research 44, 149-184.

Robbins, J.A., McCall, P.L., Fischer, J.B., Krezoski, J.R., 1979. Effect of deposit feeders on migration of ${ }^{137} \mathrm{Cs}$ in lake sediments. Earth and Planetary Science Letters 42, 277-287.

Salen-Picard, C., Graham, C., Gerino, M., 1994. Feeding ethology of infaunal polychaetous annelids: a method to determine the 
sediment layer at which food is collected. In: Dauvin, J.C., Laubier, L., Reish, D.J. (Eds.), Actes de la 4ème Conférence internationale des Polychètes, 162. Mémoire du Muséum national d'Histoire Naturelle, pp. 527-533.

Sconfietti, R., Marchini, A., Occhipinti-Ambrogi, A., Sacchi, C.F., 2003. The sessile benthic community patterns on hard bottoms in response to continental vs marine influence in northern Adriatic lagoons. Oceanologica Acta 26 (1), 47-56.

Smith, J.N., Boudreau, B.P., Noshkin, V., 1986/87. Plutonium and ${ }^{210} \mathrm{~Pb}$ distributions in northeast Atlantic sediments: subsurface anomalies caused by non-local mixing. Earth and Planetary Science Letters 81, 15-28.
Tita, G., Desrosiers, G., Vincx, M., Gagne, J.P., Locat, J., 2001. Diversity and vertical distribution of nematode assemblages: the Saguenay fjord (Quebec, Canada). Cahier de Biologie Marine 42, 263-274.

Wheatcroft, R.A., Jumars, P.A., Smith, C.R., Nowell, A.R.M., 1990 A mechanistic view of the particulate biodiffusion coefficient: step lengths, rest period and transport directions. Journal of Marine Research 48, 177-207.

Zonta, R., Zaggia, L., Argese, E., 1994. Heavy metal and grain-size distribution in estuarine shallow water sediments of the Cona Marsh (Venice Lagoon, Italy). The Science of the Total Environment 151, 19-28. 